\title{
Correction to: Dual-energy CT angiography in suspected pulmonary embolism: infuence of injection protocols on image quality and perfused blood volume
}

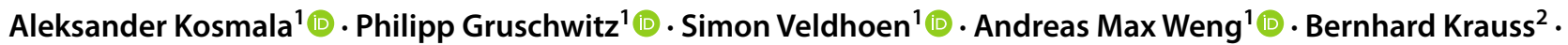 \\ Thorsten Alexander Bley ${ }^{1}$ Bernhard Petritsch ${ }^{1}$ (i)
}

Published online: 12 November 2021

(c) The Author(s) 2021

\section{Correction to: \\ The International Journal of Cardiovascular Imaging (2020) 36:2051-2059 \\ https://doi.org/10.1007/s10554-020-01911-8}

The article "Dual-energy CT angiography in suspected pulmonary embolism: infuence of injection protocols on image quality and perfused blood volume written by Aleksander Kosmala $\cdot$ Philipp Gruschwitz Simon Veldhoen - Andreas Max Weng · Bernhard Krauss - Thorsten Alexander Bley · Bernhard Petritsch", was originally published Online First without Open Access. After publication in volume 36, issue 10, page 2051-2059 the author decided to opt for Open Choice and to make the article an Open Access publication. Therefore, the copyright of the article has been changed to $\odot$ The Author(s) 2021 and the article is forthwith distributed under a Creative Commons Attribution 4.0 International License, which permits use, sharing, adaptation, distribution and reproduction in any medium or format, as long as you give appropriate credit to the original author(s) and the source, provide a link to the Creative Commons licence, and indicate if changes were made. The images or other third party material in this article are included in the article's Creative Commons licence, unless indicated otherwise in a credit line to the material. If material is not included in the article's Creative Commons licence and

The original article can be found online at https://doi.org/10.1007/ s10554-020-01911-8.

Aleksander Kosmala

Kosmala_A@ukw.de

1 Department of Diagnostic and Interventional Radiology, University Hospital Würzburg, Oberdürrbacher Straße 6, 97080 Würzburg, Germany

2 Siemens Healthcare GmbH, Research and Development, Forchheim, Germany your intended use is not permitted by statutory regulation or exceeds the permitted use, you will need to obtain permission directly from the copyright holder. To view a copy of this licence, visit https://creativecommons.org/licenses/ by/4.0. Open Access funding enabled and organized by Projekt DEAL.

The original article has been corrected.

Open Access This article is licensed under a Creative Commons Attribution 4.0 International License, which permits use, sharing, adaptation, distribution and reproduction in any medium or format, as long as you give appropriate credit to the original author(s) and the source, provide a link to the Creative Commons licence, and indicate if changes were made. The images or other third party material in this article are included in the article's Creative Commons licence, unless indicated otherwise in a credit line to the material. If material is not included in the article's Creative Commons licence and your intended use is not permitted by statutory regulation or exceeds the permitted use, you will need to obtain permission directly from the copyright holder. To view a copy of this licence, visit http://creativecommons.org/licenses/by/4.0/.

Publisher's Note Springer Nature remains neutral with regard to jurisdictional claims in published maps and institutional affiliations. 